\title{
SEASONAL AND MULTIANNUAL DYNAMICS OF RODENT SPECIES NUMBER UNDER THE INFLUENCE OF CLI- MATE FACTORS AND ANTHROPIC MODIFICATIONS
}

\author{
Veaceslav Sîtnic, Victoria Nistreanu, Alina Larion, Natalia Caraman, \\ Vladislav Caldari
}

Institute of Zoology, Chisinau, Republic of Moldova, e-mail: sitnicv@gmail.com

\begin{abstract}
The research was carried out in agricultural experiment stations in the central area of the Republic of Moldova during a period of 35 years. It was determined that cyclic oscillations with an interval of 3-4 years are not typical of Microtus arvalis, as can be seen in other parts of the area. Intense anthropogenic influence determines the type of numerical dynamics. A certain periodicity is observed in the species Mus spicilegus, but during the last 30 years the dynamics has become acyclic. In the populations of the species Apodemus sylvaticus there was a more pronounced periodicity of the oscillation of the herd, once every two years.
\end{abstract}

\section{Introduction}

Population dynamics is one of the basic problems of animal ecology, it has a great practical importance for society. Of particular interest is the oscillation of rodent numbers, which manifests itself in three temporal aspects: seasonal changes in the number, process, which takes place with the onset of reproduction and up to mortality during the generative period of one year; annual dynamics - the variation of the number of populations during different years and the multiannual dynamics, when comparing the quantitative indices during a consecutive series of years. Small rodent species have a short lifespan and breed for several generations.

The annual differences in the number of rodent populations are recorded, comparing the indices from different years, but from the same seasons. Most often the size of the herd is compared in spring, before the beginning of the breeding season or for the annual peak phase - at the end of the reproduction period. In this case, the factors that influence the existence of the population in different years (winter and spring-summer conditions) are analyzed. Therefore, the determining factors of the environmental capacity are investigated.

The multiannual dynamics of the small rodent population has been recorded since ancient times, creating difficulties for the human population in the supply of food. The peak phases were particularly pronounced for Microtus arvalis, Microtus rossiaemeridionalis, Clethrionomys glareolus, Mus spicilegus, Apodemus sylaticus etc. Their appearance in large numbers, and then their disappearance are processes which were regularly recorded and were of interest for elucidating the causes of these phenomena.

Analyzing the variation of the population, the emphasis is more on the study of the variation of reproductive intensity, but not on the causes of mortality. Only high fertility causes an increase in population. The reduction of the mortality level, the reproduction continuing to take place, have as a consequence the increase of the population density. In this case, the intrapopulation mechanisms of the inverse link act, and the reproductive potential decreases.

In order to solve the problem of rodent herd dynamics, it is necessary to divide the popu- 
lation by age groups. The nature of the periodicity of microtine population dynamics remains an enigma to this day. Several hypotheses and postulates have been formulated regarding the nature of population fluctuations, which, however, do not fully elucidate this problem. Great importance is given to the mortality factor in the dynamics of the number of the population [11]. Mortality was analyzed in light of the nutrition factor [10]. The importance of the climatic factor was demonstrated by Kalabuhov N.I. [5]. The "predator-prey" relationship was elucidated by Sludschii A.A. [12]. At the same time, a dependence of numerical dynamics on intrapopulation factors was established. Thus, Kalabuhov N.I. identified in individuals certain qualitative changes of an adaptive nature [5]. Formozov A.N. researched the reproductive potential of rodents [13]. One of the basic ecological theories - self-regulatory dynamics of livestock was substantiated by D. Chity [1]. External factors of mortality have been elucidated, causing the decline of populations: abiotics (climate, floods) and biocenotics (nutrition, predators, diseases) modifiers (environmental), dependent or independent of population density. This fact denotes the complex nature of the influence of ecological factors on microtine populations in space and time. Some ecologists consider that these populations oscillate cyclically for 3-4 years [2], others - that they have non-periodic numerical eruptions [9].

Elucidating the problem of population dynamics, a correlation of the intensity of reproduction with the phase of oscillation of the number of population was determined [7]. It is necessary to mention that the argument is the reproduction, and the consequence - the phase. Research priorities focus on the role of reproduction. It is necessary to determine the age groups (winterers, individuals in the current year, generations), which contribute to the increase of the population, which is of great importance for the elaboration of the prognosis, which is paramount in practical terms.

The problem of population dynamics is divided into two components: minor and major wave cycling [6]. The first type, of short duration, represents the result of the increase of the herd in case of a normal reproduction of the population in the conditions of favorable ecological conditions. The population goes through the peak phase over 3-5 years after the depression. The reduction of ecological capacity, the increase of mortality, as a result of unfavorable weather conditions or lack of food, move the peak phase. In this case, there is an interval of 7-8 years between these phases. So, at the base of the minor wave cycling is the high potential of reproduction in geometric progression. The study of population dynamics, at the same time as its fundamental importance, allows to formulate recommendations regarding the regulation of the number of animal individuals, their protection and rational use.

\section{Materials and methods}

The scientific material was collected from the agricultural experiment stations in the central area of the Republic of Moldova during 35 years. Field research methods related to the characteristic of structural ecological indices were used: the method of paths, the method of squares [8]. The determination of the specific composition and abundance of rodent species was performed by the methods of relative appreciation of the numerical herd - night traps, route counts, test plots, trophic activity, etc. [9], and the absolute numerical evaluation - by us- 
ing traps (four lines of 25 traps with an interval of $20 \mathrm{~m}$ ) on sample sectors with an area of 1 ha over a period of 5 days [10]. The following parameters were recorded in the captured animals: species, sex, age, physiological and reproductive status.

\section{Results and discussions}

As a result of changes in agriculture, there have been radical transformations in wildlife complexes in general and small mammal communities in particular. Often the species of this group are pests of agricultural crops. Essential changes have also taken place in the dynamics of the number of small mammals [3]. During the years of mass reproduction and rapid growth of the $M$. arvalis herd, it causes considerable damage to agriculture and, especially, to alfalfa, clover, wheat, etc. Along with this species, others such as M.spicilegus, A.sylvaticus, A.uralensis, A. agrarius, etc can cause damage too. Therefore, it is necessary to maintain an admissible density of populations of these species in concrete living conditions [4].

The climatic conditions during the study period were varied. The mildest winter was during the growing season of small mammals, when no negative temperatures were recorded. At this stage the summer was arid, with a moderate amount of precipitation. The harshest winter was for a smaller number of studied species than the multiannual average. The depression phase coincided with a snowless quite warm winter, and the drought created unfavorable conditions for reproduction.

There was a seasonal, an annual, but also a multiannual oscillation in the number of species. For the species, indicated above, an almost synchronous annual variation of the numerical number is typical. Particular attention was paid to the oscillation of the number of the main species for the respective phases of growth, maximum and depression. A significant difference in the average annual catch coefficient was established, calculated for the growth phase, maximum and depression. Thus, the significant difference of the parameter nominated in the comparative plan for the maximum phase and the depression phase for a probability $\mathrm{P}<0.05$ is $\mathrm{t}=5.6$, and for the maximum phase and the growth phase $-\mathrm{t}=8.9$. This indicates that cyclic oscillation of the number is typical of small mammals. But the length of the full oscillation cycle for each species is different.

In the $M$. arvalis species, the maximum phase is followed by a decreasing phase with a deep depression and a gradual exit from it. There will be a moderate relative growth over the next 3 years. A. sylvaticus, unlike M.arvalis, is exposed to smaller multiannual oscillations. After the year of the peak phase, the decrease phase occurs, but a deep depression is not reached, which favors in the following year an increase in the number of this species. The number of $\mathrm{M}$. spicilegus species is also exposed to oscillations, but their multiannual amplitude is smaller, registering an increase in the years, when the other species has a lower number. The dynamics of the dominant species was established during the months of the respective phases (fig.1). 


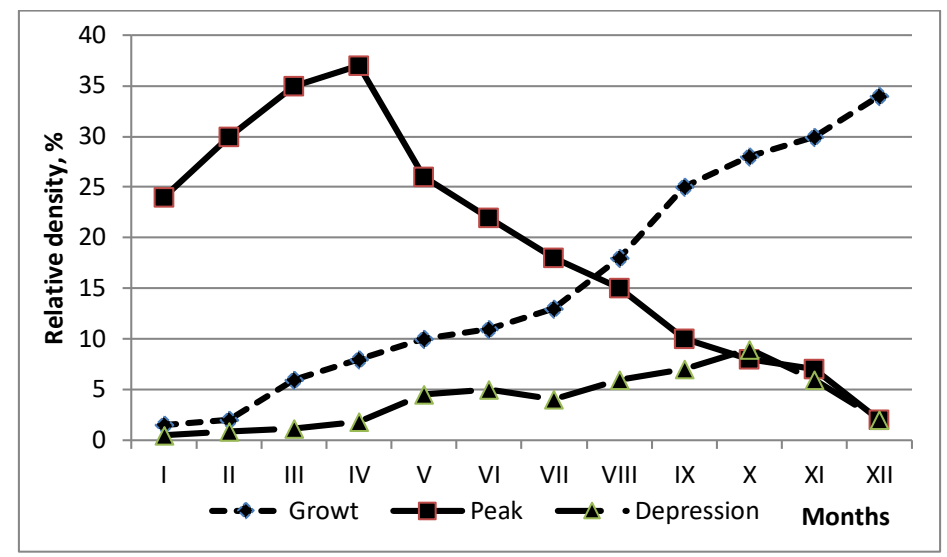

Figure 1. Seasonal dynamics of the dominant small rodent species in different phases of the population cycle

In the spring of the year of the peak phase the number is higher compared to the other phases, which contributed to its subsequent growth. Unlike other species, the number of microtines during the growth and peak phase increases from 60-70 colonies per hectare in July to 400-500 and more in late autumn. The demographic structure of the populations of the studied species represents one of the ecological parameters, which influences the oscillation of their number.

Figure 2 reflects the multiannual dynamics of the general population processes of rodent species in communities over a period of over 40 years. There is a pronounced cyclicity of the relative density of these species, the highest values of this parameter being recorded in the early and late 80 s of the past century, when multiannual forage grass crops occupied large areas and were the main feeding stations for microtine. Subsequently, with the decrease of the areas of these crops, the nutrition base for the plantivore rodent species was reduced, which also influenced the decrease in their number.

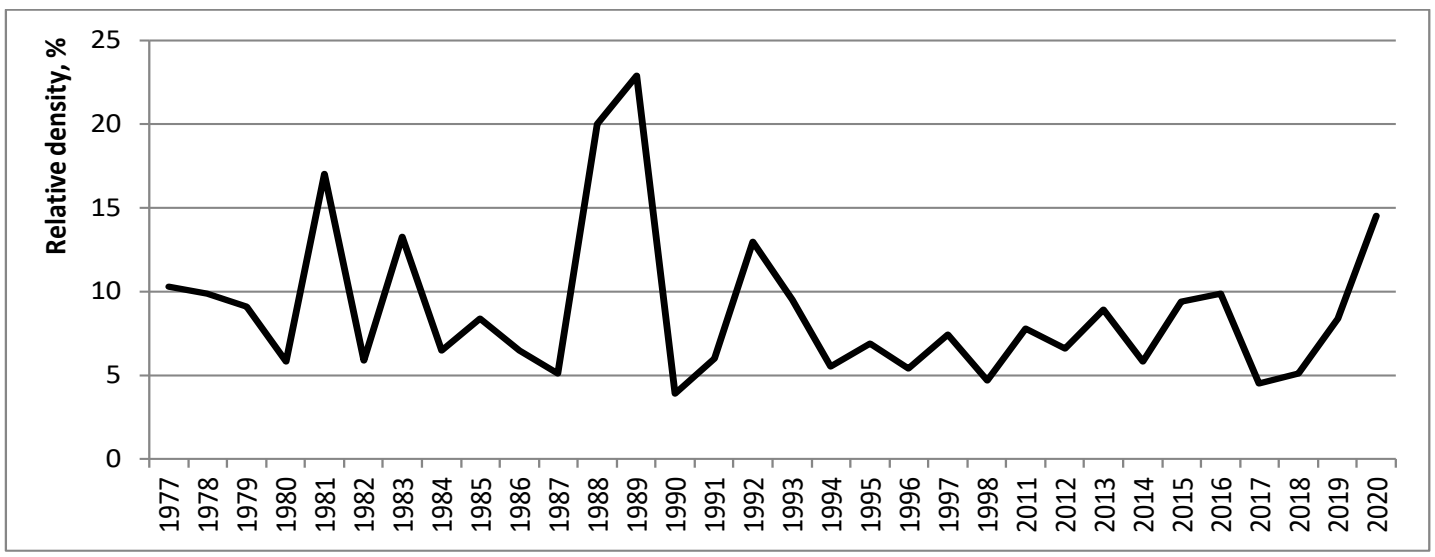

Figure 2. Multiannual dynamics of relative density of rodent species 
Figure 3 shows the multiannual dynamics of the relative density of the dominant rodent species in agrocenoses. Research has shown that the dynamics of rodent populations in agrocenosis tends to be periodic, but anthropogenic and climatic factors disrupt this process.

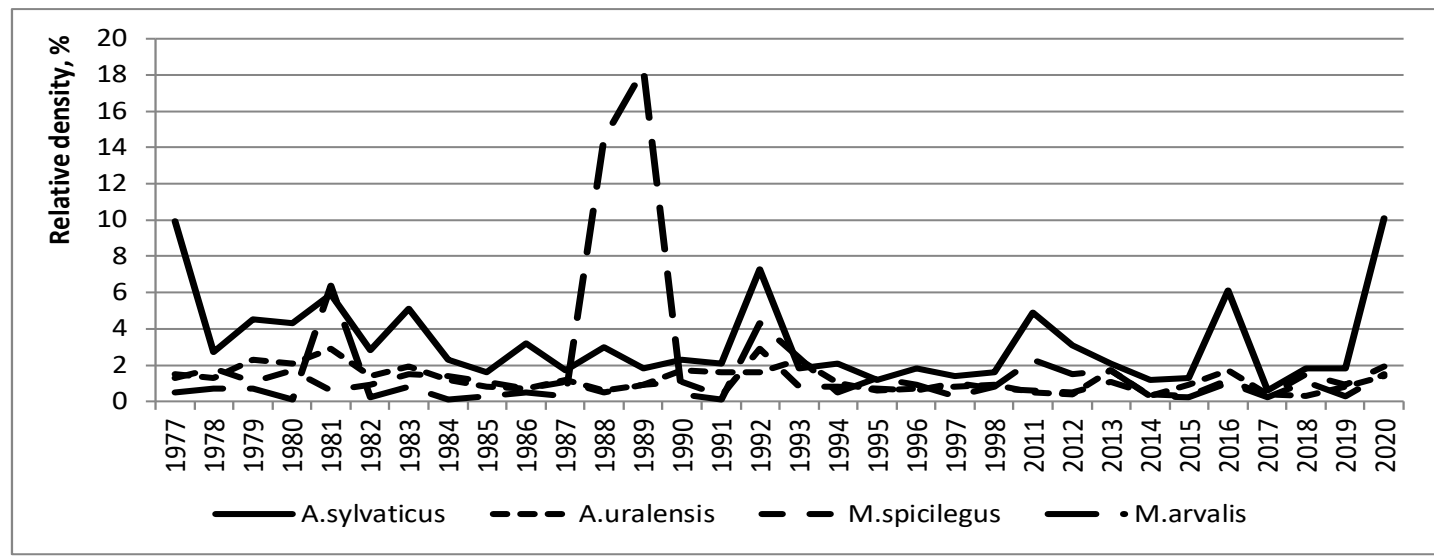

Figure 3. Multiannual dynamics of relative density of dominant rodent species in agrocenoses

Thus, for example, in Microtus arvalis, cyclical oscillations with an interval of 3-4 years are not typical, as can be seen in other parts of the area [2]. Possibly, the intense anthropic influence determines the type of numerical dynamics. A certain periodicity is also observed in the species M. spicilegus, but in the last 30 years its dynamics becomes acyclic. In the populations of the species A. sylvaticus there was a more pronounced periodicity, once every two years, of the number oscillation [3].

The multiannual cycle of microtines is divided into the following phases, which reflect the numerical strength, but also their survival. The minor undulating cycle includes the phase of depression, which is preceded by the decrease, the individuals of the population are caught more frequently in the refuge stations - the forest belts, where they survive, the living conditions during this period being unfavorable. Their density on the field of perennial grasses, adjacent to the refuge sectors, in the summer months is minimal (1-2 colonies / ha). At this stage the reproduction is manifested, but it is quite weak. In summer, the survival of the summer generation is $13 \%$, and that of the spring generation $-22 \%$. Usually, the onset of microtine populations is stimulated by unfavorable conditions, but this factor is not mandatory.

Low temperatures, rains, early frosts, unstable snow cover, frost, etc. contribute to rodent mortality. Under these conditions, at a high density, microtines suffer of food insufficiency. Usually, after the waves with a small amplitude, the reduction of the number takes place, more or less gradually, against the background of the decrease of the seasonal maximums, which is explained by the depletion of food resources. But after the significant peak phases the decrease is catastrophic and the density curve suddenly decreases.

The phase of increasing of rodent number follows the first phase after the improvement of 
living conditions in the refuge stations and outside them, this being a premise of increasing the viability of the population in these stations, increasing the density of groups, which stimulates dispersion. Outside the refuge sectors, the favorable conditions ensure the survival and intensity of the reproduction of individuals, which have dispersed.

The following factors contribute to the increase in the number of population: food supply in winter conditions, satisfactory food quality, large harvests, an optimal combination of rainfall and solar heat, which ensures the growth of crop and spontaneous plants, poor crops harvesting, reserve pastures sectors and agricultural fields, non-compliance with agrotechnical measures - shallow plowing and sowing of grass on stubble, weeding of fields and shrubs, an early spring without rapid melting, early start of plant growth, a late and warm autumn, which contributes to a second vegetation, optimal weather conditions for wintering, thick snow cover, which provides protection for microtines, but also preserves vegetation.

In this phase on the perennial grass fields the groups are made up of 2-3 colonies, which do not overlap. In late summer - early autumn the density on perennial grass fields increases to 80-100 colonies per hectare, and further - to 200-300 colonies per hectare. Survival increases from $33.7 \%$ in September to $58.6 \%$ in October, and the number of females of the late summer generation, which reproduce $(67.4 \%)$, exceeds that of spring (35.1\%). As a result, the groups disperse on the neighboring grass fields, where a density of 10-15 colonies per hectare was recorded.

The population is going through the peak phase. This is also a phase of preparation for the subsequent decline, which consists in stopping reproduction due to the physiological limit, but also stress.

Often the peak phase can take 1-2 years. The multi-annual peak phase, against the background of the large population wave, is registered under the influence of the land mosaicity.

\section{Conclusions}

It was established that the significant difference of the annual average capture coefficient in comparative plan for the maximum phase and the depression phase is $\mathrm{t}=5.6, \mathrm{P}<0.05$ and for the maximum phase and the growth phase $-t=8.9$. This demonstrates that cyclic oscillation of the number is typical of small rodents.

It was determined that for Microtus arvalis, cyclic oscillations with an interval of 3-4 years are not typical, as can be seen in other parts of the area. Intense anthropogenic influence determines the type of numerical dynamics. A certain periodicity is observed in the species $M$. spicilegus, but in the last 30 years the dynamics becomes acyclic. In the populations of $A$. sylvaticus there was a more pronounced periodicity of the number oscillation - once every two years.

During the growth phase, in autumn the density of Microtus arvalis species on perennial grass fields increases up to 200-300 colonies per hectare. Survival increases from 33.7\% in September to $58.6 \%$ in October, and the number of females of the late summer generation, which reproduce $(67.4 \%)$, exceeds that of spring $(35.1 \%)$.

The work was carried out within the State Program project 20.80009.7007.02. 


\section{Bibliography}

1. Chitty D. Population processes in rhe vol and tneer relevance to general theory. Can. J.Zool., 1977, V.38, P. 99-113

2. Munteanu A.I., Savin A.I., Sîtnic V. L. Particularităţile dinamicii numerice a comunităţilor de rozătoare în agrocenoze. În: Culegere de articole. Congresul al XVIII - lea al Academiei Româno-Americane. Chișinău, 25-26 sept.1993. Chișinău, Editura Știința, 1993. P. 22.

3. Savin A. Caracteristica ecologo-morfologică a speciilor simpatrice de rozătoare mici Apodemus sylvaticus L. și Apodemus uralensis Pall (Rodentia, Muridae) în agrocenozele Republicii Moldova. Autoreferatul tezei de doctor în științe biologice. Chişinău, 1999. 22 p.

4. Sîtnic, V., Nistreanu, V., Larion, A., Munteanu, A., Savin, A., Postolachi, V. Structura şi diversitatea comunităţilor de rozătoare mici în terenurile neprelucrate din zona centrală a Republicii Moldova. În: Buletinul AŞM. Ştiinţele vieţii. Nr. 3 (327). 2015. P.90-98.

5. Калабухов Н.И. 1950. Эколого-физиологические особенности животных и условия среды. Харьков: Изд-во Харьковск. Ун-та. 267 с.

6. Максимов А.А. 1989. Природные циклы: Причины повторяемости экологических процессов. Л.: Наука. 236 с.

7. Мунтяну А.И., Савин А.И., Патрашку В.И., Сытник В.Л. Флуктуации численности обыкновенной полёвки в агроценозах Молдавии. Мат. Всесоюз. совещ. по грызунам. Москва:Наука, 1987. Ч.2. С. 26.

8. Наумов, Н. Мечение млекопитающих и изучение их внутривидовых связей. В: Зоол. журн. 1956. N.35(1), С.3-15.

9. Никифоров И.И., Формозов А.Н. Териология. М., 1963. 396 с.

10. Новиков Г.А. Основы общей экологии и охраны природы. Л.: 349 с.

11. Северцов С.А. 1941. Динамика населения и приспособительная эволюция животных. М.Л.: Изд-во АН СССР. 316 с.

12. Слудский А.А., Борисенко В.А., Капитонов В.И. и др. 1978. Млекопитающие Казахстана. Алма-Ата: Наука. Т.1. Ч. 3. 491 с.

13. Формозов А.Н. 1940. Закономерности массовых размножений у промысловых птиц и млекопитающих. Экол. Конф., тез. Докл. Киев: Изд-во АН УССР. С. 95-96. 